\title{
Penyidikan Tindak Pidana Prostitusi secara Online
}

\section{Yolla Fitri Amilia, Haryadi, Dheny Wahyudi.}

Fakultas Hukum, Universitas Jambi

Author's email correspondence: yollaamilia09@gmail.com

\begin{abstract}
ABSTRAK
Artikel ini bertujuan untuk mengetahui dan menganalisis proses penyidikan prostitusi secara online di wilayah hukum Kepolisian Resor Kota Jambi dan mengetahui apakah hambatan dalam proses penyidikan tindak pidana prostitusi secara online di wilayah hukum Kepolisian Resor Kota Jambi. Hasil penelitian disimpulkan bahwa proses penyidikan tindak pidana prostitusi secara online yang dilakukan oleh aparat Kepolisian Resor Kota Jambi dalam menanggulangi prostitusi secara online, penyidik melakukan proses penyidikan dengan cara penyamaran dan penjebakan terhadap pelaku. Dalam hal ini yang menjadi target operasi penyidik Kepolisian Resor Kota Jambi ialah penyedia jasa pekerja seks komersil (mucikari). Selanjutnya, terkait hambatan dalam proses penyidikan tindak pidana prostitusi secara online di wilayah hukum Kepolisian Resor Kota Jambi pada kenyataannya, penyidik dalam proses penyidikan kesulitan dalam mengumpulkan alat bukti, dan kurangnya sumber daya manusia seperti ahli IT di Kepolisian Resor Kota Jambi.
\end{abstract}

Kata Kunci: Penyidikan; prostitusi online.

\section{ARTICLE HISTORY \\ Submission: 2021-03-22 \\ Accepted: 2021-04-25 \\ Publish: 2021-04-26}

KEYWORDS: Investigation; Online Prostitution

ABSTRACT
This article aims to find out and analyze the process of
investigating criminal acts of prostitution online in the
jurisdiction of the Jambi City Police and find out what are the
obstacles in the process of investigating criminal acts of
prostitution online in the jurisdiction of the Jambi City Police
Resort. The results of the study concluded that the online
prostitution crime investigation process carried out by the
Jambi City Resort Police officers in overcoming online
prostitution crimes, the investigators carried out the
investigation process by disguising themselves and trapping the
perpetrators. In this case, the operational targets of the Jambi
City Resort Police are commercial sex worker service providers
(pimps). Furthermore, related to obstacles in the process of
investigating criminal acts of prostitution online in the
jurisdiction of the Jambi City Police, in fact, investigators in the
investigation process have difficulty collecting evidence, and
lack of human resources such as IT experts at the Jambi City
Police Resort.

\section{A. PENDAHULUAN}

Dalam konstitusi, Indonesia adalah negara hukum. Sebagai negara hukum, Indonesia wajib melindungi setiap warga negaranya dari setiap perbuatan yang dapat merugikan apalagi perbuatan tersebut dapat merusak tatanan kehidupan berbangsa 
dan bernegara. Seperti halnya kejahatan yang terjadi di media internet atau biasa disebut dengan cybercrime. ${ }^{1}$

Fakta empiris dalam berbagai peristiwa trafficking perempuan dan anak adalah kelompok yang paling banyak menjadi korban tindak pidana perdagangan orang. Korban diperdagangkan tidak hanya untuk tujuan pelacuran atau bentuk eksploitasi seksual lainnya, tetapi juga mencakup bentuk eksploitasi lain, misalnya kerja paksa atau pelayanan paksa, perbudakan, atau praktik serupa perbudakan itu. Pelaku tindak pidana perdagangan orang melakukan perekrutan, pengangkutan, pemindahan, penyembunyian, atau penerimaan orang untuk tujuan menjebak, menjerumuskan, atau memanfaatkan orang tersebut dalam praktik eksploitasi dengan segala bentuknya dengan ancaman kekerasan, penggunaan kekerasan, penculikan, pemalsuan, penipuan, penyalahgunaan kekuasaan atau posisi rentan, atau memberi bayaran atau manfaat sehingga memperoleh persetujuan dari orang yang memegang kendali atas korban. ${ }^{2}$

Prostitusi merupakan penawaran hubungan seksual untuk memperoleh uang atau keuntungan lainnya. Jadi prostitusi adalah seks untuk pencaharian, terkandung beberapa tujuan yang ingin diperoleh, biasanya berupa uang. Termasuk didalamnya bukan saja persetubuhan tetapi juga setiap bentuk hubungan seksual dengan orang lain untuk mendapat bayaran. ${ }^{3}$ Penyedia jasa prostitusi via media internet kini menjadi trend bisnis prostitusi. Tak sedikit yang menjajakan dirinya dengan mendompleng situs pertemanan facebook tanpa ada yang mengkoordinir, yang jumlahnya makin hari makin bertambah.

Dalam konteks kajian hukum pidana, prostitusi online diatur dalam ${ }^{4} \mathrm{Kitab}$ Undang-Undang Hukum Pidana Pasal 296 yang menentukan:

Barang siapa dengan sengaja menyebabkan atau memudahkan perbuatan cabul oleh orang lain dengan orang lain, dan menjadikannya sebagai pencarian atau kebiasaan, diancam dengan pidana penjara paling lama satu tahun empat bulan atau pidana denda paling banyak lima belas riburupiah.

Pasal 506 yang menentukan:

Barang siapa dengan sengaja menyebabkan atau memudahkan perbuatan cabul oleh orang lain dengan orang lain, dan menjadikannya sebagai pencarian atau kebiasaan, diancam dengan pidana penjara paling lama satu tahun empat bulan atau pidana denda paling banyak lima belas riburupiah.

Selanjutnya, Pasal 27 Ayat (1) Undang-Undang Nomor 11 Tahun 2008 Tentang Informasi dan Transaksi Elektronik, yang menentukan:

1 Dheny Wahyudi, Perlindungan Hukum Terhadap Korban Kejahatan Cyber Crime Di Indonesia, Jurnal Ilmu Hukum Jambi, vol. 4, No. 1, Jul. 2013, hlm. 99. https://media.neliti.com/media/publications/43295-ID-perlindungan-hukum-terhadapkorban-kejahatan-cyber-crime-di-indonesia.pdf

2 Hafrida, Nelli Herlina, dan Zulham Adamy. The Protection of Women and Children as Victims of Human Trafficking in Jambi Province, Jambe Law Journal 1.2, 2018, hlm. 208-209. https://scholar.google.com/scholar?oi=bibs\&hl=id\&q=related:2IA0n-

HqhLMJ:scholar.google.com/

3 Topo Santoso, Seksualitas dan Hukum Pidana, Ind-Hill-Co, Jakarta, 2007, hlm. 134

4 Oksidelfa Yanto, Tindak Pidana Prostitusi (Online), 2017, hlm. 1-2. https://scholar.google.co.id/scholar?hl=id\&as sdt=0\%2C5\&q=peranan + penyidik + dalam $+m$ engungkap+tindak+pidana+prostitusi+online \&btnG= 
Setiap orang dengan sengaja dan tanpa hak mendistribusikan dan/atau menstransmisikan dan/atau membuat dapat diaksesnya Informasi Elektronik dan/atau Dokumen Elektronik yang memiliki muatan melanggar kesusilaan dipidana dengan pidana penjara paling lama 6 (enam) tahun dan/atau denda paling banyak Rp. 1.000.000.000,00 (satu miliarrupiah).

Selanjutnya Undang-Undang Nomor 44 Tahun 2008 Tentang Pornografi yaitu pada Pasal 30 Juncto Pasal 4 Ayat (1) yang menentukan:

Setiap orang yang menyediakan jasa pornografi sebagaimana dimaksud dalam Pasal 4 Ayat (2) dipidana penjara paling singkat 6 (enam) bulan dan paling lama 6 (enam) tahun dan/atau pidana denda paling sedikit Rp 250.000.000,00 (dua ratus lima puluh juta rupiah) dan paling banyak Rp. 3.000.000.000,00 (tiga miliar rupiah)

Prostitusi online melalui media sosial seperti facebook dan aplikasi messenger online seperti MiChat dan We-Chat masih menjamur di Kota Jambi. Ini dibuktikan dengan pengungkapan yang dilakukan oleh anggota Direktorat Reserse Kriminal Umum Kepolisian Polda Jambi dan juga Kepolisian Resort Kota Jambi. Seorang mucikari yang berhasil diciduk yakni RDP berusia 21 tahun, penangkapan tersebut dilakukan pada saat RDP sedang berada di loby Hotel Fortuna menunggu pekerja seks komersil (PSK) binaannya yang sedang melayani pria hidung belang di kamar hotel 107 dan $108 .{ }^{5}$

Dalam kaitannya dengan upaya perlindungan hukum terhadap korban tindak pidana perdagangan orang, maka upaya perlindungan hukum bagi masyarakat menjadi penting. Hal tersebut disebabkan masyarakat baik kelompok maupun perorangan dapat sewaktu-waktu menjadi korban kejahatan perdagangan orang. perlindungan hukum korban kejahatan perdagangan orang sebagai bagian dari perlindungan kepada masyarakat, dapat diwujudkan dalam berbagai bentuk atau model. ${ }^{6}$

Berdasarkan hasil penelitian yang penulis lakukan pada di wilayah hukum Kepolisian Resort Kota Jambi terkait pengungkapan tindak pidana prostitusi online di Kota Jambi ditemukan bahwa kasus tersebut tercatat sebanyak 14 kasus terhitung sejak tahun 2017 s/d November 2020 sebagaimana tertera pada tabel 1.

Berdasarkan penyidikan kepolisian Resort Kota Jambi diketahui, pelaku kejahatan dunia maya ini memanfaatkan aplikasi jejaring sosial Facebook dan Messenger ataupun jejaring sosial sejenisnya untuk bertransaksi seks. Sebelumnya, polisi mendapat laporan tentang sejumlah laman (situs) yang diduga melakukan praktik penyedia jasa prostitusi melalui media internet. Para pelaku membuat akun sosial media sendiri dan menampilkan sejumlah foto wanita lengkap dengan profilnya.

5 http://www.jambiupdate.co/artikel-sstt-prostitusi-online-di-jambi-abg-ditarif-rp18juta.html diakses pada tanggal 17 September 2020.

6 Yulia Monita, Perlindungan Hukum Bagi Korban Tindak Pidana Perdagangan Orang dalam Perspektif Undang-Undang Nomor 21 Tahun 2007. Inovatif: Jurnal Ilmu Hukum, vol. 6, no. 2, 2013, hlm. 168.

https://www.neliti.com/id/publications/43223/perlndungan-hukum-bagi-korban-tindakpidana-pedagangan-orang-dalam-perspektif\#cite 
Tabel 1

Pengungkapan Tindak Pidana Prostitusi Secara Online di Wilayah Hukum Kepolisian Resort Kota Jambi Tahun 2017-2020

\begin{tabular}{cc}
\hline Tahun & Jumlah Kasus \\
\hline 2017 & 7 \\
\hline 2018 & 4 \\
\hline 2019 & 2 \\
\hline November 2020 & 1 \\
\hline Jumlah & $\mathbf{1 4}$ \\
\hline
\end{tabular}

Sumber: Kepolisian Resort Kota Jambi

Langkah pertama yang dilakukan oleh bagian cyber dari unit PPA dan Tipidter Kepolisian Resort Kota Jambi dalam penyidikan perkara penyedia jasa prostitusi lewat media internet adalah melacak keberadaan pelaku dengan menelusuri informasi akun sosial media pelaku dan menambahkan kontak pelaku (add account) dalam pertemanan. Hal ini salah satu bentuk rencana penyelidikan dan penyidikan dengan cara undercover (penyamaran) yang mana hal tersebut tidak ditemukan aturannya di dalam Undang-Undang Nomor 21 Tahun 2007 Tentang Pemberantasan Tindak Pidana Perdagangan Orang, melainkan dapat ditemukan dalam kebijakan Peraturan Kepala Kepolisian RI Nomor 6 Tahun 2019 Tentang Penyidikan Tindak Pidana, lain halnya dengan ketentuan Undang-Undang Narkotika yang dengan jelas mengatur tentang undercover dalam penyidikannya.

Permasalahan hukum lainnya dalam penerapan undercover dalam penanganan tindak pidana prostitusi online masih menyisakan persoalan hukum. Undercover sebagai suatu proses dalam penyidikan sebagai upaya menegakan undang-undang perlu dikaji kembali secara komprehensif. Selanjutnya penulis menemukan fakta bahwa yang melakukan penyamaran tersebut bukanlah penyidik yang ditugaskan untuk melakukan penyidikan tersebut, melainkan orang lain yang disuruh oleh penyidik untuk memesan PSK tersebut. Jika merujuk pada ketentuan dalam Peraturan Kepala Kepolisian Republik Indonesia Nomor 6 Tahun 2019 tentang Penyidikan Tindak Pidana bahwa yang boleh melakukan penyamaran tersebut hanyalah penyidik yang ditugaskan sebagaimana tertera dalam surat perintah tugas, dan di wilayah hukum Kepolisian Resort Kota Jambi tingkat keberhasilan pengungkapan tindak pidana prostitusi online terbilang cukup rendah dibandingkan dengan daerah yang lain.

Hal ini menggambarkan bagaimana sebuah kasus seperti prostitusi secara online merupakan suatu permasalahan dalam sosiologis masyarakat yang bertentangan dengan pancasila yang sangat menjunjung tinggi norma serta nilai adat istiadat. Maka jika perbuatan prostitusi itu menjalar dan merugikan bagi masyarakat dalam hal ini negara baik secara materil atas perbuatan tersebut memberikan sanksi hukum, tetapi pengaturan hukum terhadap pelaku perbuatan prostitusi tidak ada, maka pelaku prostitusi tidak dapat di berikan sanksi hukum yang dijelaskan di dalam UndangUndang. ${ }^{7}$

Prostitusi merupakan permasalahan yang sangat kompleks karena menyangkut berbagai aspek kehidupan masyarakat dan marak terjadi di tengah masyarakat.

$7 \quad$ Ibid, hlm. 3. 
Kegiatan prostitusi menyangkut aspek sosial, gender, hukum, kesehatan, moral dan etika, agama, pendidikan, psikologis, ekonomi dan industrialisasi, dan juga masalah politik. Permasalahan yang diakibatkan oleh prostitusi, antara lain:

1. Ditinjau dari segi pendidikan, prostitusi berarti demoralisasi

2. Ditinjau dari segi sosial, prostitusi dianggap kanker masyarakat

3. Ditinjau dari sudut agama, prostitusi adalah haram

4. Ditinjau dari sudut kesehatan, prostitusi membahayakan keturunan. ${ }^{8}$

Dari keempat hal tersebut dapat dilihat bagaimana prostitusi dapat dikatakan sebagai perbuatan yang sewajarnya dijauhi oleh masyarakat. Dua hal yang pertama mengatakan bahwa perbuatan prostitusi itu merupakan bentuk demoralisasi dan kanker masyarakat. Hal tersebut menunjukkan bagaimana tercelanya perbuatan prostitusi itu di mata masyarakat. 9

Dalam hal ini masyarakat di tuntut untuk lebih menghormati norma dan nilai yang terdapat di kehidupan masyarakat karena masalah prostitusi online ini dapat menghancurkan masa depan bangsa seperti adanya kasus yang di temukan dengan pelaku penyedia jasa prostitusi online yang masih remaja dan kurang tegasnya peraturan Perundang-undangan yang dipergunakan menjerat pelaku penyedia jasa prostitusi online.

Untuk menelusuri latar belakang seseorang menyambangi pekerjaan prostitusi sangatlah sulit dimanapun, karena masalah yang melingkupinya sudah jelas dan saling erat berkaitan dari sebab yang satu kesebab yang lainnya. Namun faktor-faktor yang ada dapat dibedakan secara garis besarnya, diantaranya yaitu faktor moral atau ahlak, faktor psikologis hubungan keluarga yang berantakan, faktor biologis, faktor ekonomi dan faktor sosiologis. ${ }^{10}$

Fenomena dalam latar belakang masalah ini diperlukan suatu upaya pembangunan hukum terkait dengan pengaturan penerapan undercover untuk menjamin kepastian hukum, sehingga tidak terjadi salah kaprah dalam penegakan hukum. Hal ini mengacu pada peraturan terkait dengan pemberantasan tindak pidana prostitusi online di Indonesia, diperlukan suatu upaya dalam pembangunan hukum kedepannya untuk mewujudkan keadilan Berdasarkan uraian diatas, maka dari itu dirumuskan masalah bagaimana proses penyidikan prostitusi secara online di wilayah hukum Kepolisian Resort Kota Jambi?, dan apakah hambatan dalam proses penyidikan prostitusi secara online di wilayah hukum Kepolisian Resort Kota Jambi?.

\section{B. METODE PENELITIAN}

Metode penelitian yang penulis gunakan dalam penelitian ini ialah yuridis empiris, yaitu dengan melihat secara langsung fakta-fakta yang terdapat di lapangan terkait penyidikan tindak pidana prostitusi secara online di wilayah hukum Kepolisian Resort Kota Jambi juga melihat aturan perundang-undangan yang mengatur tentang protitusi online ini.

8 Sri Novi Anggita, Penerapan Hukum Terhadap Jaringan Mucikari Dalam Praktek Prostitusi, Skripsi, Fakultas Hukum Unversitas Negeri Medan, 2018, hlm. 13

9 Ibid, hlm. 14.

10 Farhana, Aspek Hukum Perdagangan Orang di Indonesia, Sinar Grafika, Jakarta, 2010, hlm. 50. 


\section{PEMBAHASAN}

1. Proses Penyidikan Tindak Pidana Prostitusi Secara Online di Wilayah Hukum Kepolisian Resort Kota Jambi

Dalam mengungkapkan kasus protitusi online ini maka sangat di perlikan sekali , Profesionalisme polisi dalam menangani masalah penyakit masyarakat salah satunya tindak pidana asusila dan haruslah dilandasi oleh aturan hukum yang pasti. UndangUndang Kepolisian Negara Republik Indonesia (UU Nomor 2 Tahun 2002) merupakan suatu undang-undang yang mengatur perihal kepolisian. Sebagai pengaturan dasar tugas dan fungsi polisi maka dalam penanganan tindakan asusila seorang polisi harus bertugas dan berfungsi secara profesionalisme sebagaimana diamanatkan oleh Undang-Undang Kepolisian Negara Republik Indonesia.

Sebagai suatu tindak pidana meskipun dalam lingkungan penyakit masyarakat, maka perihal telah terjadinya prostitusi secara online maka pihak kepolisian merupakan pihak yang berhak menerima serta memprosesnya kasus yang terjadi. Berdasarkan hasil penelitian yang penulis lakukan, di wilayah Kepolisian Resort Kota Jambi tercatat sebanyak 14 kasus prostitusi online sejak tahun 2017 sampai dengan Januari 2021 sebagaimana tertera pada tabel di bawah ini:

Tabel 2

Pengungkapakan Tindak Pidana Prostitusi Secara Online di Wilayah Hukum Kepolisian Resort Kota Jambi Tahun 2017 - Januari 2021

\begin{tabular}{ccc}
\hline $\begin{array}{c}\text { Nomor Perkara } \\
\text { Jmb }\end{array}$ & Terdakwa & Klasifikasi Perkara \\
\hline $\begin{array}{c}\text { 34/Pid.Sus/2019/PN } \\
\text { Jmb }\end{array}$ & Elpa Mayang Sari Als Caca & Pemberantasan TPPO \\
\hline $\begin{array}{c}\text { 765/Pid.Sus/2018/PN } \\
\text { Jmb }\end{array}$ & Riri Dwi Putri Als Riri & Pemberantasan TPPO \\
\hline $\begin{array}{c}\text { 121/Pid.Sus/2018/PN } \\
\text { Jmb }\end{array}$ & Bunga Safitri Liya & Pemberantasan TPPO \\
\hline $\begin{array}{c}\text { 101/Pid.Sus/2018/PN } \\
\text { Jmb }\end{array}$ & Ria Marianti Als Ria & Pemberantasan TPPO \\
\hline $\begin{array}{c}\text { 32/Pid.Sus/2018/PN } \\
\text { Jmb }\end{array}$ & Indah Sari Als Mumu & Pemberantasan TPPO \\
\hline $\begin{array}{c}\text { 940/Pid.Sus/2017/PN } \\
\text { Jmb }\end{array}$ & Rani Iranti Desiyani Als Ranyra & Pemberantasan TPPO \\
\hline $\begin{array}{c}\text { 917/Pid.Sus/2017/PN } \\
\text { Jmb }\end{array}$ & Erwin Hidayat & Pemberantasan TPPO \\
\hline $\begin{array}{c}\text { 824/Pid.Sus/2017/PN } \\
\text { Jmb }\end{array}$ & Dwi Cahyarini Alias Ririn & Pemberantasan TPPO \\
\hline $\begin{array}{c}\text { 825/Pid.Sus/2017/PN } \\
\text { Jmb }\end{array}$ & Rowy Tampani Alias Roy & Pemberantasan TPPO \\
\hline $\begin{array}{c}\text { 731/Pid.Sus/2017/PN } \\
\text { Jmb }\end{array}$ & Ardini Mahallisa & Pemberantasan TPPO \\
\hline \begin{tabular}{c} 
420/Pid.Sus/2017/PN \\
\hline
\end{tabular} & Sugiarto Alias Sugi & Pemberantasan TPPO \\
\hline
\end{tabular}




\begin{tabular}{ccc}
\hline Jmb & & \\
\hline $\begin{array}{l}\text { 278/Pid.Sus/2017/PN } \\
\text { Jmb }\end{array}$ & Aries Situmorang, Sp & Pemberantasan TPPO \\
\hline
\end{tabular}

Sumber: Data Hasil Penelitian Lapangan

Penanganan prostitusi online di Polresta Jambi yaitu sebagaimana berdasarkan hasil wawancara penulis dengan Bapak Hendra Situmeang, selaku Penyidik Unit PPA Polresta Jambi menyatakan bahwa:

Beberapa kasus yang di proses berkaitan dengan protitusi online, berawal pelaporan dari pihak korban dan saksi, pihak kepolisian akan melangkah ke Lidik. Pada proses ini, pihak kepolisian melakukan beberapa langkah antara lain :

1. Interview adalah:

a. Tanya jawab dengan seseorang untuk dimintai pendapat atau keterangan suatu hal (bukan pemeriksaan)

b. Cara untuk mendapatkan keterangan atau pendapat dalam bentuk Tanya jawab tentang sesuatu hal yang perlu memperoleh kejelasan oleh pejabat, narasumber, ahli atau yang berkepentingan untuk itu.

2. Observasi adalah Pemantauan, cara pengawasan dengan teliti atau peninjauan secara cermat terhadap objek tertentu untuk memperoleh informasi secara langsung tentang sesuatu yang dilakukan dalam rangka penyelidikan.

3. Surveillance adalah Pengawasan, pengamatan atau pembuntutan secara tertutup untuk memperoleh informasi atau dlam rangka pengumpulan buktibukti.

4. Undercover adalah Penyelidikan tertutup kegiatan atau usaha penyelidikan yang dilakukan oleh penyidik Polri secara tertutup atau rahasia tetapi objek tidak mengetahui kegiatan tersebut. ${ }^{11}$

Maka dapat diketahui bahwa langkah yang dilakukan pihak kepolisian diantaranya dimulai dengan interview guna mengetahui tentang prostitusi online yang marak beredar di media sosial. Selanjutnya dilakukan observasi dan diteruskan dengan surveillance hingga akhirnya dilakukan penyelidikan tertutup (undercover) dengan melakukan penyamaran untuk menjebak mucikari dan mengungkapkan jaringan yang lebih besar lagi. Selanjutnya, menurut keterangan Bapak Hendra Situmeang bahwa:

Dalam hal ini kepolisian bisa melakukan penahanan terhadap tersangka. Tujuannya agar pihak tersangka tidak melakukan tindakan seperti :

1. Tidak melakukan intimidasi kepada pihak korban atau keluarga korban.

2. Tidak menghilangkan barang bukti atas kejahatannya.

3. Tidak melarikan diri atas tindak kejahatannya. ${ }^{12}$

Setelah berhasil dijebak, maka dilakukanlah penangkapan. Penangkapan dalam hal ini dilakukan secara tangkap tangan maupun dengan cara razia penyakit masyarakat yang dilakukan oleh tim Opsnal Polresta Jambi. Sehingga proses tindak pidana tersebut, bisa berjalan aman dan terkendali. Menurut Bapak Hendra Situmeang hal ini menjadikan proses penyidikan tidak memiliki kendala. ${ }^{13}$

Berdasarkan hasil wawancara penulis dengan Ibu Chrissvani Stevani mengatakan bahwa:

11 Hasil Wawancara

12 Hasil Wawancara

13 Hasil Wawancara 
Jika proses Lidik telah selesai, maka pihak kepolisian melaksanakan Sidik, dimana proses Sidik terdiri dari :

1. Lidik atau penyelidikan adalah Serangkaian tindakan penyelidik untuk mencari dan menemukan suatu peristiwa yang diduga sebagai tindak pidana guna menentukan dapat atau tidak nya dilakukan penyidikan menurut cara yang diatur dalam undang-undang ini.

2. Tindak atau penyidikan adalah Serangkaian tindakan penyidikan dalam hal dan menurut cara yang diatur menurut undang-undang ini untuk mencari serta mengumpulkan bukti yang dengan bukti itu membuat terang tentang tindak pidana yang terjadi dan menemukan tersangkanya.

3. Riksa atau pemeriksaan adalah Kegiatan atau sifat menyelidik terhadap suatu objek orang atau barang untuk mendapatkan keterangan yang berkaitan dengan masalah atau kepentingan tertentu.

4. Serahkara atau penyerahan perkara adalah dalam hal penyidik telah selesai melakukan penyidikan, penyidik wajib segera menyerahkan berkas perkara itu kepada penuntut umum. ${ }^{14}$

Proses penyidikan prostitusi online di wilayah hukum Kepolisian Resort Kota Jambi, penyidik melakukan proses penyidikan dengan cara penyamaran dan penjebakan terhadap pelaku. Dalam hal ini yang menjadi target operasi penyidik kepolisian resort kota jambi ialah penyedia jasa pekerja seks komersil (mucikari). Berdasarkan hasil penelitian yang penulis peroleh diketahui bahwa, dasar dilakukannya penyidikan tersebut berpedoman kepada:

1. Kitab Undang-Undang Hukum Acara Pidana (Undang-Undang Nomor 8 Tahun 1981)

2. Undang-Undang RI Nomor 2 Tahun 2002 Tentang Kepolisian Negara Republik Indonesia

3. Peraturan Pemerintah RI Nomor 27 Tahun 1983 Tentang Pelaksanaan KUHAP.

4. Perkapolri Nomor 6 Tahun 2019 Tentang Penyidikan Tindak Pidana

Pada prosesnya diketahui dari keterangan Bapak Akbar selaku Penyidik Unit PPA Polresta Jambi, beliau mengemukakan beberapa hal diantaranya, bahwa: "Peristiwa ataupun praktik prostitusi online tersebut diketahui dari masyarakat yang membicarakan tentang aplikasi MiChat". ${ }^{15}$ Selanjutnya, pada aplikasi MiChat tersebut akan dilihat pada bio akun yang menawarkan jasa prostitusi. Berdasarkan keterangan Bapak Akbar selaku Penyidik, beliau menyatakan bahwa:

Kami menggunakan handphone android milik kantor (khusus) untuk mencari akun yang menawarkan prostitusi tersebut, dengan mengatur lokasi radius 3-15 Km banyak ditemukan akun yang menawarkan diri yang dapat dilihat dari bio mereka yang mencantumkan ST/LT, Open Bo, Cash, Cari yang mau BO, COD di Kamar, ST (tarif). ${ }^{16}$

Untuk memberantas tindak pidana prostitusi online yang semakin menjamur di Kota Jambi, aparat kepolisian resort Kota Jambi terus melakukan beberapa rangkaian tahapan dan tidak segan melakukan razia pekat dan juga melakukan penyidikan secara menyamar dan menjebak tiap pelaku. Jika diperhatikan, penangkapan terhadap pelaku

Hasil Wawancara

15 Hasil Wawancara

16 Hasil Wawancara 
tindak pidana prostitusi online dilakukan secara tangkap tangan. Dalam hal ini maka tindak pidana ditemukan oleh polisi.

\section{Hambatan Dalam Proses Penyidikan Tindak Pidana Prostitusi Secara Online di Wilayah Hukum Kepolisian Resort Kota Jambi}

Ada beberapa hambatan yang dihadapi oleh pihak kepolisian dalam menangani beberapa kasus mengenai prostitusi online berdasarkan wawancara langsung dari pihak Penyidik unit PPA Polresta Kota Jambi, kendala tersebut antara lain:

\section{a. Keberagaman Undang-Undang yang Diberlakukan}

Salah satu kendala yang cukup sulit untuk ditangani dalam kasus prostitusi melalui media sosial online, yaitu pihak kepolisian sedikit kesulitan untuk menentukan Undang-Undang yang akan dipakai untuk menjerat pelaku. Seperti yang kita ketahui dalam kasus tindak pidana prostitusi online terdapat keberagaman Undang-Udang yang berlaku di Indonesia. Pihak kepolisian hanya bertugas untuk menjerat perbuatan yang ada dalam Undang-Undang, bukan sebagai pembuat Undang-Undang, sehingga di perlukan ketelitian dan kecermatan dalam melihat perbuatan apa yang dilakukan pelaku dan pasal apa yang akan di terpakan pada pelaku, hal ini juga berkaitan bahwa penyidik bisa menganalisa apakah unsur=unsur pidananya sudah terpenuhi, sehingga prosesnya bisa dilanjutkan ke kejaksaan dan pengadilan. Berdasarkan hasil wawancara penulis dengan Kepala Unit PPA Polrsta Jambi, Ibu Chrisvani Stevani beliau menyatakan bahwa:

Jika dalam kasus prostitusi yang biasa, pelaku dijerat dengan Pasal 296 KUHP serta Pasal 506 KUHP karena mengandung unsur prostitusi sebagai pencaharian dan terdapat mucikari di dalamnya. Namun pada kasus Prostitusi secara Online ini karena menggunakan media sosial online maka tidak bisa dijerat dengan Pasal yang berada di KUHP, dan mengacunya pada UndangUndang Nomor 11 Tahun 2008 tentang Informasi Teknologi dan Elektronik pada Pasal 27 ayat (1) yang karena mengandung unsur kesusilaan, tetapi pada Pasal itu pun tidak menyebutkan kata "prostitusi", lalu ditambahlah dengan Undang-Undang Nomor 21 Tahun 2007 Pemberantasan Tindak Pidana Pemberantasan Orang, maka kasus ini mengacu pada tindak pidana perdagangan orang. Jika pihak korban masih dibawah umur, pengaturannya menggunakan Undang-Undang Nomor 23 Tahun 2002 Tentang Perlindungan Anak. ${ }^{17}$

Berdasarkan hal tersebut diketahui bahwa keberagaman Undang-Undang dalam penegakan hukum tindak pidana prostitusi di Indonesia menjadikan salah satu hambatan penyidik dalam menerapkan Pasal dalam penyelidikannya, sehingga penyelidik harus dengan cermat mengidentifikasi dugaan tindak pidana yang diketahui, apakah bisa di proses dan apakah ada pelanggaran pidana.

\section{b. Kesulitan Mengumpulkan Alat Bukti}

Penyidikan merupakan suatu rangkaian proses mengumpulkan alat bukti dan tersangka. Dalam tindak pidana prostitusi online penyidik merasa kesulitan mengumpulkan alat bukti yang cukup, sehingga dengan adanya kebijakan Peraturan Kepala Kepolisian RI Nomor 9 Tahun 2019, penyidik ataupun penyelidik dapat melakukan penyamaran (undercover) untuk membantu penyidik dalam hal memberantas tindak pidana prostitusi online tersebut. Hal ini diketahui dari hasil

17 Hasil Wawancara 
wawancara penulis dengan salah satu Penyidik Unit PPA Polresta Jambi, Bapak Akbar beliau menyatakan bahwa:

Sebelum melakukan penyidikan, kami melakukan gelar perkara dan menyusun rencana penyidikan yang akan dilakukan. Karena dalam UndangUndang Nomor 21 Tahun 2007 Tentang Pemberantasan Tindak Pidana Perdagangan Orang tidak mengatur tata cara penyidikan, maka kami dengan kebijakan Perkapolri Nomor 6 Tahun 2019 menentukan melakukan penyidikan dengan cara undercover (penyamaran) untuk mengumpullkan alat bukti dan menetapkan tersangkanya. ${ }^{18}$

Dari hal itu dapat diketahui bahwa penyidik hanya dapat mengumpulkan bukti dan menemukan tersangkanya hanya dengan melakukan cara undercover (penyamaran), jika proses ini tidak dilakukan sulit sekali untuk mengumpulkan bukti apa yang pelaku sudah lakukan.

\section{c. Identitas Pelaku sering dipalsukan}

Dalam menangani beberapa kasus prostitusi online, dari pihak kepolisian mengalami sedikit terganggu berkaitan dengan masalah identitas pelaku maupun korban, karena setiap kali mereka beroperasi selalu menggunakan identitas samaran agar jejaknya tidak diketahui oleh apparat, sehingga sulit untuk dikenali ataupun dilacak. Berdasarkan hasil wawancara dengan Bapak Hendra Situmeang, salah satu dari Penyidik di Unit PPA Polresta Jambi beliau menyatakan bahwa:

Adapun nama yang digunakan pada akun MiChat yang tercantum bukanlah nama yang sebenarnya, mereka sengaja menggunakan nama-nama yang menarik agar orang lain terkesan. Dan tidak jarang juga mereka melakukan penipuan, dimana ketika uang telah ditransferkan ke $e$-wallet mereka malah memblokir kontak kita. ${ }^{19}$

Dari hal tersebut dapat diketahui bahwa pelaku ataupun target operasi sudah menyiapkan penyamaran dan bahkan sampai menipu pelanggan untuk kepentingan pribadinya, sehingga ini menjadi salah satu hambatan penyidik dalam menemukan tersangkanya.

\section{d. Sumber Daya Manusia Dalam Bidang Teknologi Informasi Terbatas}

Kemajuan teknologi yang semakin canggih dan kurangnya pengetahuan dan pelatihan terhadap aparat penegak hukum di Polresta Jambi menjadikan hal ini sebagai hambatan. Berdasarkan hasil wawancara penulis dengan Bapak Dendy Krisandi, Penyidik Unit Tipidter Polresta Jambi beliau menyatakan bahwa, "Sumber Daya Manusia yang ahli dalam bidang cybercrime sangat terbatas, sehingga tidak semua pihak Satreskrim ahli di bidang tersebut". ${ }^{20}$

Tidak adanya ahli IT dalam proses penyidikan tindak pidana prostitusi online di wilayah hukum Kepolisian Resort Kota Jambi juga menjadikan hambatan penyidik dalam mengungkap tindak pidana prostitusi online itu sendiri. Dengan tidak adanya orang yang ahli pada bidang tersebut membuat kinerja dan profesionalitas penyidik tidak berjalan dengan maksimal. 


\section{SIMPULAN}

Proses penyidikan yang dilakukan oleh aparat Kepolisian Resort Kota Jambi dalam menanggulangi tindak pidana prostitusi secara online, penyidik melakukan beberapa tahapan dalam, diantaranya melalui proses penyidikan dengan cara penyamaran dan penjebakan terhadap pelaku. Dalam hal ini yang menjadi target operasi penyidik kepolisian Resort Kota Jambi ialah penyedia jasa pekerja seks komersil (mucikari). Hambatan yang dialami pihak kepolisian Polresta Kota Jambi di dalam proses penyidikan diantaranya dalam mengumpulkan alat bukti yang cukup dan menetapkan tersangka. Hal ini dikarenakan tidak adanya aturan khusus tentang penyidikan terhadap tindak pidana prostitusi online, sehingga penyidik melakukan penyidikan dengan cara undercover yang sebagaimana diatur dalam Perkapolri Nomor 6 Tahun 2019 Tentang Penyidikan Tindak Pidana, selanjutnya keberagaman undangundang yang mengatur tindak pidana prostitusi online, pelaku memalsukan identitas aslinya, dan sumber daya manusia yang kurang professional dalam menghadapi kasuskasus yang berkaitan dengan kejahatan dunia maya (cybercrime).

\section{DAFTAR PUSTAKA}

\section{Dokumen Hukum}

Republik Indonesia,Undang-Undang Republik Indonesia Nomor 8 Tahun 1981 Tentang Hukum Acara Pidana. LNRI Tahun 1981 Nomor 76, TLNRI Nomor 5145.

Republik Indonesia, Undang-Undang Nomor 21 Tahun 2007 Tentang Pemberantasan Tindak Pidana Perdagangan Orang. LNRI Tahun 2007 Nomor 58, TLNRI Nomor 4720.

Republik Indonesia, Undang-Undang Nomor 11 Tahun 2008 Tentang Informasi dan Transaksi Elektronik. LNRI Tahun 2008 Nomor 58, TLNRI Nomor 4843.

Republik Indonesia, Undang-Undang Nomor 44 Tahun 2008 Tentang Pornografi. LNRI Tahun 2008 Nomor 181, TLNRI Nomor 4928,

Peraturan Kepala Kepolisian Negara Republik Indonesia Nomor 6 Tahun 2019 Tentang Penyidikan Tindak Pidana.

\section{Buku:}

Farhana, Aspek Hukum Perdagangan Orang di Indonesia, Sinar Grafika, Jakarta, 2010.

Anggita, Sri Novi. Penerapan Hukum Terhadap Jaringan Mucikari Dalam Praktek Prostitusi, Skripsi, Fakultas Hukum Universitas Negeri Medan, 2018.

Santoso, Topo. Seksualitas dan Hukum Pidana, Ind-Hill-Co, Jakarta, 2007. 
Jurnal:

Hafrida, Nelli Herlina, and Zulham Adamy. "The Protection of Women and Children as Victims of Human Trafficking in Jambi Province." Jambe Law Journal 1.2 (2018). DOI: https://doi.org/10.22437/jlj.1.2.207-230

Kartika, Yuni \& Andi Najemi. (2020). “Kebijakan Hukum Perbuatan Pelecehan Seksual (Catcalling) dalam Perspektif Hukum Pidana" Pampas: Journal of Criminal Law, $1.2(2020)$.

DOI: https://doi.org/10.22437/pampas.v1i2.9114

Monita, Yulia. "Perlindungan Hukum Bagi Korban Tindak Pidana Perdagangan Orang dalam Perspektif Undang-Undang Nomor 21 Tahun 2007." Inovatif: Jurnal Ilmu https://online-journal.unja.ac.id/jimih/article/view/2124Hukum, 6. 2 (2013).

Wahyudi, Dheny. "Perlindungan Hukum Terhadap Korban Kejahatan Cyber Crime Di Indonesia" Jurnal Ilmu Hukum Jambi, 4.1 (2013).

https://online-journal.unja.ac.id/index.php/jih/article/view/1972

Yanto, Oksidelfa. Tindak Pidana Prostitusi (Online), (2017). http://eprints.unpam.ac.id/id/eprint/6082 